e-ISSN: 2550-1313 | p-ISSN: 2087-9849

http://jurnal.fkip.unila.ac.id/index.php/jpp/

\title{
Managerial Leadership Principal of Senior High School: Case Studies in SMAN 2 Bandar Lampung, Indonesia
}

\author{
Sowiyah $^{1 *}$, Ryzal Perdana ${ }^{2}$ Farhan Baehaki $^{3}$ \\ ${ }^{1}$ Department of Education Administration, Universitas Lampung, Indonesia \\ ${ }^{2}$ Department of Educational Science, Universitas Lampung, Indonesia \\ ${ }^{3}$ Medical Laboratory Technology, Institut Kesehatan Rajawali, Bandung, Indonesia \\ *Corresponding email: sowi.unila@gmail.com
}

Received:06 September $2021 \quad$ Accepted: 14 December $2021 \quad$ Published: 25 December 2021 Abstract: Managerial Leadership Principal of Senior High School: Case Studies in SMAN 2 Bandar Lampung, Indonesia. Objective: This study aims to analyze and describe the managerial leadership of the Principal of State Senior High School 2 Bandar Lampung, Indonesia. Methods: This research uses a matching method with quantitative and qualitative approaches. The research was conducted at State Senior High School 2 Bandar Lampung with the number of respondents as many as 60 teachers in the school environment. Findings: Data obtained through field observations, questionnaires and supported by interviews and documentation. The results show that (1) principal managerial leadership in conceptual skills involves teacher participation in order to create an effective school, (2) there is a synergy of a harmonious relationship between leaders and teachers in realizing school achievement, and (3) mapping the development of leadership techniques skills for principals. and the acceleration of the residence period of students and an increase in the quality of the master program in educational management.

Keywords: effective school management, teachers, quality of school.

Abstrak: Kepemimpinan Menejerial Kepala Sekolah Menengah Atas: Studi kasus pada SMAN 2 Bandar Lampung, Indonesia. Tujuan: Penelitian ini bertujuan untuk menganalisis dan mendeskripsikan kepemimpinan manajerial Kepala Sekolah Menengah Atas Negeri 2 Bandar Lampung, Indonesia. Metode: Penelitian ini menggunakan metode matching dengan pendekatan kuantitatif dan kualitatif. Penelitian dilakukan di SMA Negeri 2 Bandar Lampung dengan jumlah responden sebanyak 60 orang guru di lingkungan sekolah. Data diperoleh melalui observasi lapangan, angket dan didukung dengan wawancara dan dokumentasi. Temuan: Hasil penelitian menunjukkan bahwa (1) kepemimpinan manajerial kepala sekolah dalam keterampilan konseptual melibatkan partisipasi guru dalam rangka mewujudkan sekolah yang efektif, (2) adanya sinergi hubungan yang harmonis antara pemimpin dan guru dalam mewujudkan prestasi sekolah, dan (3) pemetaan pengembangan keterampilan teknik kepemimpinan bagi kepala sekolah. serta percepatan masa tinggal mahasiswa dan peningkatan kualitas program magister manajemen pendidikan.

Kata kunci: manajemen sekolah efektif, guru, kualitas sekolah.

\section{To cite this article:}

Sowiyah., Perdana, R., \& Baehaki, F. (2021). Managerial Leadership Principal of Senior High School: Case Studies in State Senior High School 2 Bandar Lampung, Indonesia. Jurnal Pendidikan Progresif, 11(3), 692-705. doi: 10.23960/jpp.v11.i3.202120. 


\section{INTRODUCTION}

Schools are important media to achieve goals in educating the nation's life. School is a place to develop the potential of students. The development of student potential is very important to be able to face the challenges of the world, where basically it is a process to actualize and express capabilities. To be able to organize a quality education system, schools must have a systematic management system. This system will work if the principal is able to be a good leader.

The quality of education in schools cannot be separated from the leadership qualities of the principal. This is because the principal is an important part of the role of educator, manager, administrator, supervisor, leader, innovator, and motivator (Indonesia Ministry of National Education, 2006; Nur \& Imron, 2020; Sulistiyani et.al 2020). The leadership of the principal will affect the achievement of the school's vision and the implementation of the system (Mustiningsih, 2013; Pauliene, Diskiene, 2019). The optimal implementation of the system will result in the achievement of the school's vision because each individual in the organization has worked well according to their respective duties (Kitur K., Choge J., Tanui, 2020) Of course this can be realized if the principal is able to guide, supervise and evaluate the operation of the system. When the principal is able to do this well, his role will be positively influential in the professional progress of a teacher (Koutouzis, \& Malliara, 2017; Anastasiou, \& Papakonstantinou, 2014; Rachmawati, Suyatno, \& Santosa 2020).

A school principal must have an effective leadership style so that the process of coaching, monitoring, and evaluation in the organization he is fostering does not experience major obstacles so that the obstacles that hinder the process of achieving the school's vision can be overcome easily (Bass, 1969; Putri, Bafadal, \& Juharyanto 2020; Daft, 1999; Umeh, 2008; Anastasiou \& Garametsi, 2020).
The ability of the principal is a requirement as a leader who must always follow the development of science and technology because changes in the world of education are always happening (Anastasiou, \& Papakonstantinou, 2015; Mullakhmetov, Aminova, Filimonchuk 2019) A leader of an institution needs knowledge intelligence, emotional intelligence, and always innovates. Thus a change in conditions will be obtained in the organization he leads, where the school under his guidance will become a school that continues to develop, innovate and move in accordance with existing changes (Mullakhmetov, Sadriev, Gabaidullina, \& Aminova, 2017). So that the school's vision will be realized easily.

The achievement of the vision of the school which is related to the success of education is the success of the system that operates in the school. The success of the system means that the organizational wheels running in the school are optimal so that each individual moves according to their respective duties (Yukl, 2010; Gibson, John, Donnelly, Konopaske, 2012; Kinicki \& Williams, 2009). Success in moving the wheels of the organization is the duty of a school principal who is elected to be the leader of an organization or institution. The principal as the leader of the organization must have an effective leadership spirit to be able to influence its members so that the organization can run according to the vision that has been made together and strives to create a conducive school situation and build communication that is mutually respectful, trusting, open, and responsible (Gibson, John, Donnelly, \& Konopaske, 2012; Aygeros, 2009).

The success of this system can be seen from the development of schools in implementing the learning system and the enthusiasm of the community to become part 
of the system. The quality of a good school will determine parents' decisions when choosing a school as a place to study (Phillippo \& Griffin, 2016) One of the schools that falls into this category is State Senior High School 2 Bandar Lampung in Lampung Province, Indonesia. Along with its development, State Senior High School 2 Bandar Lampung has become a target for the community to direct their children to continue their studies. This raises the opinion that State Senior High School 2 Bandar Lampung is the favorite school in Lampung Province. This is in accordance with its vision, namely Excellence, Cultured and Character to remain a leading school in Lampung Province, Indonesia.

State Senior High School 2 Bandar Lampung is a senior high school developed under the auspices of the Ministry of Education and Culture of the Republic of Indonesia. State Senior High School 2 Bandar Lampung as a formal educational institution that plays an important role in the development process of students based on their characteristics, development of knowledge, development of their talents to gain achievement and changes in attitudes for the better. So that schools can produce quality human resource products and will be the pride of all parties, especially parents.

Based on the results of observations at State Senior High School 2 Bandar Lampung, the realization of the results of quality human resource products from educational success is the achievement obtained by students, both academic and non-academic. Achievements are obtained individually and in groups, from championships at the city, provincial, national and international levels. The achievement starts from the winner of the runner-up, 1st place, 2 nd place, $3 \mathrm{rd}$ place, favorite to the overall champion, as evidenced by the many trophies and certificates of achievement owned by State Senior High School
2 Bandar Lampung. Of course, this condition will support students to continue to develop their potential so that they have qualified skills and will be able to compete effectively in the era of globalization (Leite, 2020).

This is certainly a reflection of the success of the system implemented in State Senior High School 2 Bandar Lampung. The role of the principal is an aspect that becomes the center of attention because it is able to manage the system properly so that the system runs optimally. Every individual in the organization, in this case the school, has carried out their duties properly. Based on this, it is necessary to conduct observational research on the managerial leadership of the head of State Senior High School 2 Bandar Lampung.

\section{METHODS}

This study uses the matching method. The use of this method is treated with two analyzes, namely quantitative and qualitative analysis (Creswell, 2009). The research was conducted at State Senior High School 2 Bandar Lampung. This research begins by exploring the implementation of personal roles, school institutions, professional organizations, colleges, and other institutions that contribute to developing the principal managerial leadership. The number of respondents in this research is 60 people who are teachers at State Senior High School 2 Bandar Lampung. Data was collected by filling out a questionnaire about the management skills of school principals which included conceptual skills, social skills, and technical skills. Meanwhile, to obtain more in-depth information is done by conducting interviews, observation, and documentation study.

In general, the stages in research include literature study, questionnaire preparation, data collection (quantitative and qualitative), and data analysis. The research stages can be seen in Figure 1. Literature studies were carried out through 
theoretical studies of managerial leadership in related books or journals. The preparation of questionnaires and interview sheets was also carried out based on the results of theoretical studies so that the questions did not deviate from the research objectives. To see whether the questions on the questionnaire and interview sheet are appropriate or not, validity and reliability tests are conducted (Baehaki, Nahadi, \& Firman, 2017). The validity test is carried out based on the CVR (Content Validity Ratio) value which involves the assessment of instruments by experts. There were seven experts involved consisting of three research methodology experts and four education management experts. Meanwhile, the reliability test is carried out statistically by looking for the Cronbach's Alpha value. Valid and reliable question items can be used for data collection while invalid and reliable questions are discarded or corrected according to expert input.

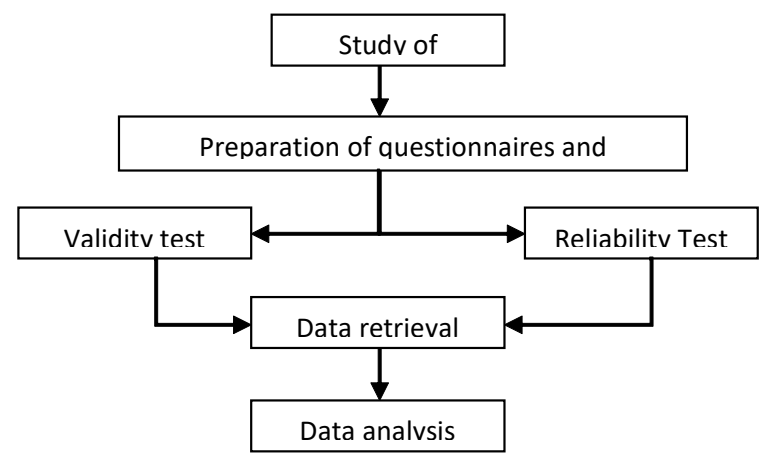

Figure 1. Steps taken in research

\section{- RESULT AND DISCUSSIONS \\ Instrument Validity and Reliability}

The validity and reliability tests were carried out on the three questionnaires that were compiled, namely the social aspect questionnaire, the technical aspect questionnaire, and the conceptual aspect questionnaire. The validity data can be seen in Table 1. In the social aspect questionnaire, 23 questions were compiled and all of them had good validity. Likewise, the technical and conceptual aspects of the questionnaire with 26 and 25 questions respectively have good validity. This can be seen in the CVR value in Table 1, for the number of experts as many as seven people, the critical CVR value is 0.622 , while the CVR value for the questions in each questionnaire has a minimum value of 0.714 . This shows that the CVR value of the items is above the critical CVR value so that all items can be said to be valid.

Validity is defined as validity or meaningfulness in which a measuring instrument can measure what you want to measure and according to certain criteria (Adeleke, and Joshua, 2015; Arikunto, 2008; Drost, 2011; Baehaki, Nahadi, and Firman, 2017; Thoha, 1994). The CVR value shows the suitability of the question with the objectives to be achieved, in this case it is the information you want to extract. When the CVR value is above the critical CVR value, then the question item is in accordance with the purpose of the question. Therefore, it can be said that the compiled questionnaire can be used for appropriate data collection.

Table 1. Data validity of research instruments

\begin{tabular}{llc}
\hline & & Value \\
\hline Social aspect & $\mathrm{N}$ & 23 \\
questionnaire & Critical CVR & 0.622 \\
& CVR minimum & 0.714 \\
& CVR maximum & 1 \\
\hline Questionnaire for & $\mathrm{N}$ & 26 \\
technical aspects & Critical CVR & 0.622 \\
& CVR minimum & 0.714 \\
& CVR maximum & 1 \\
\hline Conceptual aspect & $\mathrm{N}$ & 25 \\
questionnaire & Critical CVR & 0.622 \\
& CVR minimum & 0.714 \\
& CVR maximum & 1 \\
\hline
\end{tabular}

To see the reliability of the items in the questionnaire, statistical analysis was carried out by looking for the Cronbach's Alpha value. This reliability value is related to the reliability of the instrument in measuring. Table 2 shows the results of the data analysis on the reliability of the question items. 
Table 2. Results of questionnaire reliability analysis

\begin{tabular}{lcc}
\hline & Cronbach's Alpha & N of Items \\
\hline Social aspect questionnaire & .933 & 23 \\
\hline Questionnaire for technical aspects & .972 & 26 \\
\hline Conceptual aspect questionnaire & .953 & 25 \\
\hline
\end{tabular}

When Cronbach's Alpha value gets closer to 1 , it can be said that the question has good reliability. The data in Table 2 shows that the questionnaire compiled has very good reliability where the value of $\alpha>0.9$ (Gliem, J. A. and Gliem, R.R 2003). This shows that the questionnaire has good reliability because it relates to the extent to which a measuring instrument provides a truly reliable picture (Firman, 2000) This means that this value provides information about the consistency or consistency of the instruments developed to carry out testing (Arikunto, 2008; Firman, 2000; Baehaki F., Nahadi, and Firman, 2017). Therefore, the social aspect questionnaire, the technical aspect questionnaire, and the conceptual aspect questionnaire that were compiled can be used to collect data in this study.

\section{Testing Data Analysis Requirements \\ Data Normality Test}

The normality test is carried out to see the reasonableness of the data obtained. The

Table 3. Data normality test results

\begin{tabular}{llccc}
\hline & & Conceptual & Social & Technical \\
\hline $\mathrm{N}$ & & 60 & 60 & 60 \\
\hline \multirow{2}{*}{ Normal Parameters } & & 67.67 & 73.40 & 72.40 \\
\cline { 2 - 5 } Most Extreme Differences & Mean & 6.641 & 10.916 & 14.280 \\
\cline { 2 - 5 } & Std. Deviation & .075 & .089 & .069 \\
\cline { 2 - 5 } & Absolute & .060 & .084 & .068 \\
\cline { 2 - 5 } & Positive & -.075 & -.089 & -.069 \\
\cline { 2 - 5 } & Negative & .075 & .089 & .069 \\
\hline Test Statistic & & $.200^{\mathrm{c}, \mathrm{d}}$ & $.200^{\mathrm{c}, \mathrm{d}}$ & $.200^{\mathrm{c}, \mathrm{d}}$ \\
\hline Asymp. Sig. (2-tailed) & & & &
\end{tabular}

normality test is performed using the Kolomogorov-Smirnov test. The results of the normality test from the data obtained can be seen in Table 3.

The data in Table 3 shows that overall all data groups are normally distributed. This can be seen from the Asymp value. Sig. (2-tailed) obtained by 0.200 . This is because when the Asymp. Sig. (2-tailed) $>0.05$, then the data is included in the normal distribution category. And vice versa, when the Asymp. Sig. (2-tailed) $<0.05$, then the data is in the abnormal category.
The normal distribution of data allows a parametric statistical test to be carried out (Sugiyono, 2012).

\section{Data Homogeneity Test}

The variable homogeneity test aims to test whether the assumptions for ANOVA are valid, namely whether the three samples have the same variant. If the data is not included in the homogeneous category, the ANOVA test cannot be performed. The homogeneity test was carried out by looking at the Levene Test value and can be seen in Table 4. 
Table 4. Data homogeneity test results

\begin{tabular}{cccc}
\hline Levene Statistic & df1 & df2 & Sig. \\
\hline 1.417 & 2 & 177 & .245 \\
\hline
\end{tabular}

In Table 4, it can be seen that the Levene Test obtained is 1.417 with a probability value of 0.245 . Because the value of Probability / Sig. $>$ 0.05 , it can be said that the three variables are identical or the data group is included in the homogeneous category so that ANOVA analysis can be carried out.

\section{Hypothesis test}

After the three variables proved to be homogeneous, the ANOVA test was performed to test the three variables. Decision making is done based on the significance value (Sig.). If the value is Sig. $>0.05$, it can be said that the managerial score between conceptual, social, and technical aspects does not have a significant difference. And vice versa, if the value is Sig. $<0.05$, it can be said that the managerial scores between conceptual, social and technical aspects have significant differences. This means that the three variables have a strong relationship to determine the managerial leadership quality of the principal.

\section{Post Hoc: Tukey Test Dan Bonferroni Test}

Post Hoc test is conducted to see which data groups are different and which data groups are the same. So that it can be seen which aspects

Table 5. Results of the data analyst using the ANOVA test

\begin{tabular}{lccccc}
\hline & Sum of Squares & df & Mean Square & F & Sig. \\
\hline Between Groups & 1314.844 & 2 & 657.422 & 6.301 & .002 \\
\hline Within Groups & 18466.133 & 177 & 104.328 & & \\
\hline Total & 19780.978 & 179 & & & \\
\hline
\end{tabular}

affect the quality of the principal's leadership more. Table 6 shows the data from the Post Hoc analysis using the Tukey Test and Bonferroni Test. The conceptual aspect has the greatest difference with a score of 5.733 on the social and technical aspects. This shows that the conceptual aspect determines the quality of school principals. This means that good conceptual competencies will improve the managerial quality of school principals.

Table 6. Results of Data Analysis Using the Post Hoc Test

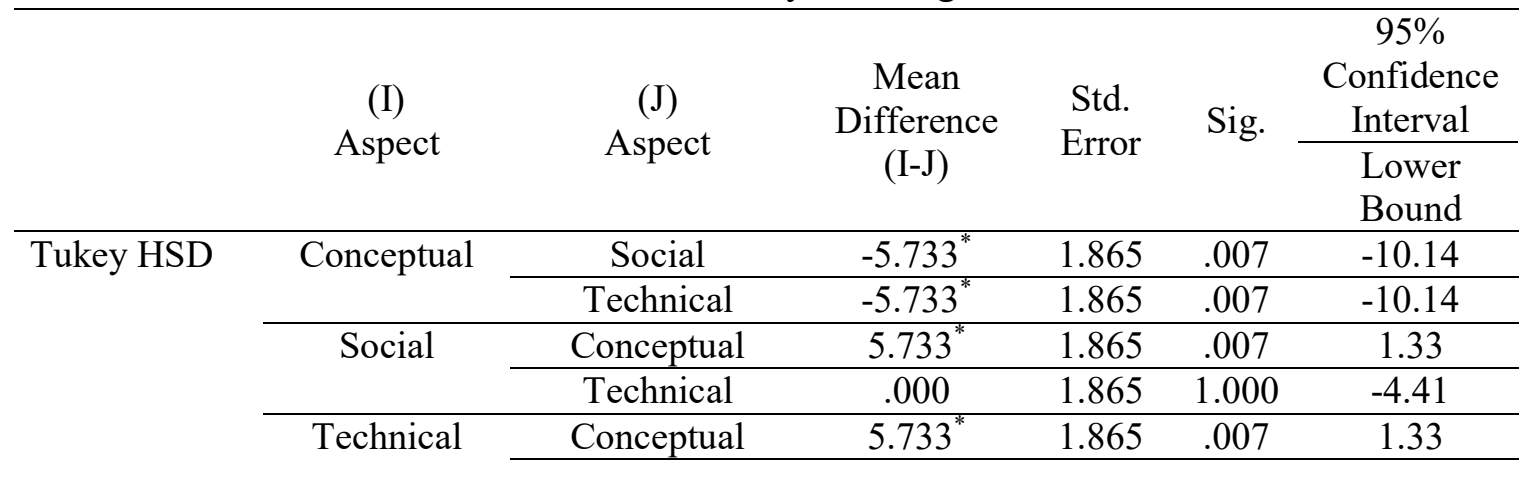




\begin{tabular}{ccccccc} 
& & & & & & \\
\cline { 3 - 6 } Bonferroni & Conceptual & Social & .000 & 1.865 & 1.000 & -4.41 \\
\cline { 3 - 6 } & & Social & $-5.733^{*}$ & 1.865 & .007 & -10.24 \\
\cline { 2 - 6 } & Social & Technical & $-5.733^{*}$ & 1.865 & .007 & -10.24 \\
\cline { 2 - 6 } & & Conceptual & $5.733^{*}$ & 1.865 & .007 & 1.23 \\
\cline { 2 - 6 } & Technical & .000 & 1.865 & 1.000 & -4.51 \\
\cline { 2 - 6 } & \multirow{2}{*}{ Technical } & Conceptual & $5.733^{*}$ & 1.865 & .007 & 1.23 \\
\cline { 3 - 6 } & & Social & .000 & 1.865 & 1.000 & -4.51 \\
\cline { 3 - 6 } & & & & &
\end{tabular}

\section{Qualitative Analysis}

Principal Managerial Leadership in Conceptual Aspects

The author conducted interviews, made observations and took documentation to determine managerial leadership carried out by the head of State Senior High School 2 Bandar Lampung. First, the authors conducted an interview with the principal of State Senior High School 2 Bandar Lampung in relation to managerial leadership carried out by the principal in managerial leadership in the conceptual aspect. Respondents stated that:

"Yes, we always carry out principal managerial leadership in the conceptual aspect by means of decision-making involving stakeholders, such as educators, education staff, and school committees, decision making through a quality cluster consisting of experts or well-established practitioners, a learning management control team and participatory school decisions “.

Respondents also explained that they had carried out conceptual aspects in the leadership of the principal, namely by making decisions involving many parties, such as educators, education staff, and school committees, making decisions through quality clusters consisting of senior educators in science and learning methodology, committee members The school consists of experts or well-established practitioners, a team that controls participatory learning management and school decisions. Because the principal stated that this was a managerial leadership factor in the principal's managerial leadership, then the authors asked the principal what strategies the school did in making decisions before the implementation of managerial leadership was carried out and why it was done in the decision-making process, the principal stated:

"The decision-making process is carried out by listening to opinions during coordination meetings between school principals, teachers and staff with the aim that any decisions made by the principal are not impressed based on unilateral decisions." To strengthen the principal's comments, the author triangulated by interviewing Teacher 1, he stated that: "In making policies and decisions before there is change, always listen to opinions during coordination meetings between school principals, deputy principals, teachers and staff." In addition to interviewing Teacher 1, the author conducted interviews with other teachers to strengthen the principal's comments, namely Teacher 2, stating that: "Before there is a change in decision making by hearing opinions during a coordination meeting between school principals, deputy head teachers and staff' Teacher 3 , the vice principal of the curriculum field, stated that: "Prior to making changes in decision-making by hearing opinions during coordination meetings between school principals, field staff, teachers and staff' Another thing was conveyed by Teacher 3 , stating that:

"After there is a conceptual aspect by the principal in terms of decision making, it has involved various stakeholders, such as teachers, and school committees, through quality consisting of senior teachers in science and learning 
methodology, school committee members from experts or established practitioners, the team learning management controller participatory school decisions"

Teacher 4, one of the teachers confirmed the previous principal's opinion that: 'Decision-making in our school involves many parties, such as teachers, and school committees, which through the quality cluster consist of teachers in science and learning methodologies who are quite senior, members of the school committee from experts or established decision practitioners, learning management control teams and decisions school in a participatory manner" Teacher 5 stated also that: "In decision making, apart from involving many parties, such as teachers and school committees, also through a quality cluster consisting of senior teachers in science and learning methodology, school committee members from well-established experts or practitioners, the learning management control team and school decisions in a participatory manner"

Based on the results of the interviews, it can be concluded that the process in conceptual aspects such as decision-making by principals often even always involves many parties or various stakeholders, such as educators, education personnel, and school committees, besides that decision making through quality assurance consists of teachers- teachers in science and learning methodology are considered experienced, as well as members of the school committee from experts or well-established and professional practitioners, the learning management control team and school decisions in a participatory way. Good managerial leadership of school principals is conceptually capable of producing quality school decisions, both quantitative and qualitative, which are capable of creating positive, rational, and objective changes for the school organization. The decision of the principal in question must have dynamic and innovative access to his leadership. For more details, the principal managerial leadership in the conceptual aspect can be seen in Table 7 .

With regard to the findings obtained in the statistical analysis of the questionnaire and the results of the researcher interviews, it was found that the managerial leadership of the principal at State Senior High School 2 Bandar Lampung was going well. The results of the distribution of research questionnaires to schools showed good results. The validity and reliability of the research instrument make it easy for researchers to map the expected managerial leadership variables of school principals.

From the conceptual aspect, there is a slight difference in values between one school and another, this researcher believes that there are differences in individual school principals in addressing the problems that exist in their educational institutions. The character of the leader greatly influences the conceptual aspects of the principal. This is supported by the statement that a leader is essentially someone who has the ability to influence the behavior of others in his work by using power (Pauliene, Diskiene, and Matuzeviciute 2019).

This means that the better and higher the conceptual aspects of the Principal's managerial leadership, the better and higher the performance of the school teacher. The better the activities carried out by the principal in making plans to organize all school activities, and evaluating activities, the higher the performance of the teaching staff. This result is in line with the opinion of Anastasiou Garametsi, (2020) that the effectiveness of one's work is strongly influenced by the rules that must be obeyed by everyone in the organization. According to Katz, quoted by Stooner, M. J. A. F and Wemkel, (1993) that a leader has the ability to organize and integrate all the interests and activities of the organization. 
Principal Managerial Leadership in Social Aspects

In essence, humans are individual as well as social beings, from birth to death humans need to be assisted or collaborated with other humans, all the happiness that humans feel is basically thanks to the help and cooperation with other humans, humans realize that they must feel their heart called to do good. for others and society). Social competence according to Mustafa, Berani, Berisha (2019) is a person's ability to communicate, socialize, cooperate, and give to others. In line with this thinking, Schein, (2004) defines social competence as (1) a person's ability to interact and communicate with colleagues to improve professional abilities; (2) the ability to recognize and understand the functions of each social institution and; and (3) the ability to establish cooperation either individually or in

Table 7. Managerial leadership of school principals in decision making

\begin{tabular}{cc}
\hline & Managerial leadership by principals in Conceptual Aspects \\
\hline Aspect & Conceptual decision making \\
\hline
\end{tabular}

Before

The decision-making process is carried out by listening to opinions during coordination between school principals, teachers and staff

Decision-making involves many parties, such as teachers and school committees, decision-making through a quality cluster consisting of

Managerial Leadership senior teachers in science and learning methodology, school committee members from well-established experts or practitioners, learning management control teams, participatory school decisions

groups. Based on the above limitations, what is meant by social competence is the ability of a school principal to cooperate with others, care socially and have social sensitivity. Managerial leadership by the principal in the social aspect can be divided, among others:

\section{a) Principal's Social Competence}

Researchers conducted interviews with the principal of State Senior High School 2 Bandar Lampung in relation to managerial leadership carried out by the principal in the social aspect. Respondents stated that: "In relation to the social aspect, where there are many systematic and realistic learning programs. Because after being met in the field, sometimes the learning program must be adjusted to the existing environment, so as the head of the school institution, the principal invites all educators and school stakeholders to improve performance in order to help students and improve academic and non-academic achievement. By inviting dialogue in various matters, so that communication is maintained, so that the school climate runs well and is able to create a conducive educational climate."

Respondents admitted that they often even always took the principal's managerial leadership in the social aspect. He believes that his competence in the social aspect is able to create a conducive climate in the school 
institution he leads. To strengthen the comments of the principal of State Senior High School 2 Bandar Lampung, the researcher triangulated by interviewing one of the subject teachers, namely Teacher 1 , he stated that: "Before starting teaching and learning activities, every day the principal routinely provides positive input to educators, so that they always maintain communication between educators and school management, this opens a way for us to always be positive so that the educational climate in our school is maintained".

This comment was corroborated by Teacher 2 who stated that: "Our school principal always tries to dialogue with us as often as possible both individually and in groups, in addition to strengthening in terms of teaching, the principal also provides directions so that we can always communicate both during school hours and outside school hours". It can be concluded that the social aspect of the principal's managerial leadership, in terms of social competence, the principal tries as often as possible or even always communicates positively with educators and education staff to create a conducive school climate.

\section{b) Principal's Social Aspect Factors}

Researchers conducted interviews with the principal of State Senior High School 2 Bandar Lampung in relation to the social aspects of managerial leadership carried out by the principal, the respondents stated that: "The factor of being able to communicate positively is for the children of students. They are a mandate that must be maintained. So that the best must be given to them, it is definitely the best for educators and education staff, because if the educator is positive then the students think positively".

Respondents admitted that they had made changes in a more effective communication process. The person to person approach is very effective in the communication process. To strengthen these comments, the researcher triangulated by interviewing the deputy head of the student affairs department, he stated that: "The principal always provides positive input to us, the management as well as the educators and education staff so that they always prioritize the interests of students"

c) Principal Social Competence Development Researchers conducted interviews with the principal of State Senior High School 2 Bandar Lampung, namely in relation to changes made by schools in the development of school principals' social competence, respondents stated that: "In terms of developing the principal's social competence, I always and regularly visit classes during school hours, visit office spaces where teachers socialize. Then routinely in meetings of school heads and trainings"

Respondents admitted that they have done routine things in the implementation of social competency development. Always develop competence by visiting the class during school

Table 8. Managerial leadership of school principals in social aspects

\begin{tabular}{ll}
\hline \multicolumn{2}{c}{ Managerial Leadership Head of School Social Aspect } \\
\hline Aspect & \multicolumn{1}{c}{ Social Competence } \\
\hline Before & $\begin{array}{l}\text { In general, all teaching staff still need guidance } \\
\text { and direction in order to prepare teaching and } \\
\text { learning activities }\end{array}$ \\
2. $\begin{array}{l}\text { Itis still found that the implementation of teaching } \\
\text { and learning activities has not yet reached the set }\end{array}$ &
\end{tabular}


curriculum target

3. In general, teachers do not have enough knowledge in order to assemble learning outcome evaluation questions including how to follow up on test results

4. Not yet effective social communication Managerial Leadership

1. There is a learning program that is systematic and realistic, correct and efficient in order to help students and improve the administrative system

2. Teaching and learning activities according to the syllabus quickly and effectively because they are carried out by the teachers in accordance with the time determined by the school

3. Each subject teacher prepares a perfect test kit. Each teacher carries out an evaluation in accordance with applicable guidelines for the formation of effective communication

hours, visiting the teacher's room and communicating with educators, and routinely in order to achieve the expected goals. To strengthen these comments, the researcher triangulated by interviewing Teacher 3 , stating that: "The principal always visited us in class during school hours. The principal is also often present in the teacher's room for dialogue or discussion about". The school principal admitted that he had tried to do routine things in the implementation of social competency development. Always develop competence by regularly attending meetings of school principals.

Factors that influence leaders and subordinates are the expectations and behaviors displayed by superiors in forming cooperation within the organization. Likewise, Pauliene, Diskiene, and Matuzeviciute (2019) suggest that human relations skills, communication skills, teaching skills, social skills, and technical skills are characteristics that a school manager must have. The results of research on principal managerial leadership in the social aspect show positive things, this proves that the better the activities that the principal does in establishing cooperation, communication, motivation and resolving conflicts will always be followed by an increase in the performance of educators.

\section{Principal Managerial Leadership in Technical Aspects}

Respondents admitted that the principal had made technical changes in organizing and managing the administrative system, for example in the student sector, namely by preparing an administrative system using computerization which included several student activities, including: filing / correspondence system, recording student master books, administration of Student Admissions New, administration of national examinations, administration of grades / leggers, reports (New Student Admissions, National Examinations, class advancement, student success). For more details, the changes made by the principal in the student sector can be seen in Table 9.

This is reinforced by several theories put forward by Koutouzis, and Malliara, (2017) that 
the high level of skills possessed by their operational executors still requires direction, guidance, and development. Furthermore, supported byAnastasiou, and Papakonstantinou (2015) as the principal is obliged to foster and guide teachers to be able to carry out the teaching and learning process properly. The principal is also obliged to control how teaching is carried out by educators. The results showed that the better the activities carried out by the principal in guiding the teaching staff, the teaching and learning process, guiding the teaching staff in implementing school administration, the better the performance of the teaching staff would be followed.

\section{CONCLUSIONS}

In general, the results of this study indicate the principal managerial competence as an effort to improve the quality of education in Indonesia. The results obtained are the conceptual aspects that the researchers found in the field have different values due to the individual factors of the principal's character which make managerial leadership aspects have a different impact. The higher the value of the conceptual aspect of the principal, the better the climate and quality of education in the school.

In particular, the results of this study provide the development of a new competency model that is used for teacher development and training programs in Indonesia based on managerial leadership, especially in the conceptual, social, and managerial aspects of principal managerial leadership. In addition, the results of this study provide information and identification and help formulate problems in the managerial competency development program of school principals in Indonesia, and can also be used as the basis for making a blueprint map for the development of school principal leadership in Bandar Lampung City based on managerial competence.

\section{ACKNOWLEGMENTS}

The authors are grateful to Universitas Lampung, Universitas Sebelas Maret, and Institut Kesehatan Rajawali, who were willing to cooperate in completing this research. The authors also want to thank all those who have helped both material and moral so that this research can be carried out well.

\section{- REFERENCES}

Adeleke, A. A. and Joshua, E. O. (2015). Development and Validation of Scientific Literacy Achievement Test to Assess Senior Secondary School Students' Literacy Acquisition in Physics. Journal of Education and Practice, 6(7), 28 - 42. Anastasiou, S and Garametsi. (2020). Teachers' Views on The Prioroties of Effective School Management. Journal of Educational and Social Research, 10(1), 1-10

Anastasiou, S., \& Papakonstantinou, G. (2014). Factors affecting job satisfaction, stress and work performance of secondary education teachers in Epirus, NW Greece. International. Journal of Management in Education, 8(1), 37-53.

Anastasiou, S., \& Papakonstantinou, G. (2015). Greek high school teachers' views on principals' duties, activities and skills of effective school principals supporting and improving education. International Journal of Management in Education, 9(3), 340-358.

Arikunto, S. (2008). Dasar-Dasar Evaluasi Pendidikan (Edisi Revisi). Jakarta: PT. Bumi Aksara.

Aygeros, S. (2009). Effective Principals and secondary education schools. A critical theoretical view on the selection-evaluation and role of Principals. [Hellenic Open University]. In Patras, Greece. https:// apothesis.eap.gr/handle/repO/19148 
Baehaki F., Nahadi, and Firman, H. (2017). Pengembangan Tes Pilihan Ganda Berbasis Penalaran Untuk Mengukur Penguasaan Materi Kesetimbangan Kimia. Seminar Nasional Kimia Dan Pendidikan Kimia IX (SNKPK IX). Solo : Universitas Sebelas Maret.

Bass, F. M. (1969). Anew product growth model for consumer durables. Management Science, 15(5), 215-227.

Creswell, J. W. (2009). Research Design: Qualitative, Quantitative, and Mixed Methods Approaches. Los Angeles: Sage.

Daft R.L. (1999). Leadership Theory and Practice. Orlando USA. The Dryden Press.

Drost, E. A. (2011). Validity and Reliability in Social Science Research. Education Research and Perspectives, 38(1), 105 $-123$.

Firman, H. (2000). Penilaian Hasil Belajar Dalam Pengajaran Kimia. Bandung: PMIPA UPI.

Garametsi, A. S. and. (2020). Teachers' Views on The Prioroties of Effective School Management. Journal of Educational and Social Research, 10(1), 1-10.

Gibson, J. L., John M. I, Donnelly, J. H. Jr, dan K. R. (2012). (2012). Organizations Behavior-Structure-Processes (Fourteenth). New York: Mc Graw Hill Companies.inc.

Gliem, J. A. and Gliem, R. R. (2003). Calculating, Interpreting, and Reporting Cronbach's Alpha Reliability Coefficient for Likert-Type Scales. Midwest Research-to-Practice Conference in Adult, Continuing, and Community Education.

Indonesian Ministry of Nastional Education (2006). Standar Kopetensi Kepala Sekolah TK, SD, SMP, SMA, SMK \& $S L B$. BP. Jakarta: Cipta Karya.
Kinicki A, and Brian K.W. (2009). Management A Pratical Introduction (Fourth edi).USA: Mc.Graw-Hill.

Kitur K., Choge J., Tanui, E. (2020). Relationship between Principals' Transformational Leadership Style and Secondary School Students' Academic Performance in Kenya Certificate of Secondary Education in Bomet County, Kenya. Universal Journal of Educational Research, 8(2), 402-409.

Koutouzis, M., \& Malliara, K. (2017). Teachers' Job Satisfaction: The Effect of Principal's Leadership and Decision- Making Style. International Journal of Education, 9(4), 71-89.

Leite, I. (2020). Society, Public Policies and Education: Alternative Approaches in Uruguay. Journal for Critical Education Policy Studies, 18(1).

Mullakhmetov, K. S., Sadriev, R. D., Gabaidullina L. A., \& Aminova, R. M. (2017). The effective System of Management Control as a factor of a successful Lean Management at the Russian Enterprises. Revista Publicando, 1390-9304.

Mullakhmetov K.S., Aminova R.M., F. I. I. (2019). Administrative Innovations as Necessary Condition of Competitiveness in Schools. Journal of Educational and Social Research, 9(4), 21-26.

Mustafa S., Berani F., B. H. (2019). Managing Organizational Conflicts: A Study among Organizations in Kosovo. Journal of Educational and Social Research, 9(1), 29-35.

Mustiningsih. (2013). Pengantar Kepemimpinan Pendidikan. Malang: Fakultas Ilmu Pendidikan Universitas Negeri Malang.

Nur M. Z. A., Imron A., and A. I. (2020). The Principal Role as a Caregiver in Forming Students Character: A Study in Al-Izzah 
Secondary Boarding School Malang-East Java Indonesia. Research,. Universal Journal of Educational, 8(5), 17671771.

Pauliene R., Diskiene, D., and M. E. (2019). Complex Approach on Multicultural Teams Management \& Leadership. Journal of Educational and Social Research, 9(2), 8-16.

Phillippo, K. and Griffin, B. (2016). "If you don't score high enough, then that's your fault": Student civic dispositions in the context of competitive school choice policy. Journal for Critical Education Policy Studies, 14(2).

Putri F.F., Bafadal I., J. (2020). Kepemimpinan Kepala Sekolah Berprestasi. JAMP: Jurnal Adminitrasi Dan Manajemen Pendidikan, 71 - 83.

R.L, D. (1999). Leadership Theory and Practice. The Dryden Press.

Rachmawati Y., Suyatno, S. A. B. (2020). Principal's Managerial Competence in Actualizing a Creative School. Universal Journal of Educational Research, 8(8), 3406-3416.

Schein, E. H. (2004). Organizational Culture \& Leadership. San Francisco: Jossey Bass.

Stooner, M. J. A. F and Wemkel, C. (1993). Perencanaan dan Pengambilan Keputusan dalam Manajemen. Alih Bahasa Sahat Semamora. Jakarta: PT Rineka.

Sugiyono. (2012). Memahami Penelitian Kualitatif. Jakarta: Bumi Aksara.

Sulistiyani Puteri Ramadhani, Arita Marini,A. M. (2020). Implementasi Pendidikan Multikultural Dilihat dari PerspektifGuru, Kepala Sekolah dan Kegiatan Siswa diSekolah Dasar. Jurnal BASICEDU, 5(1), 140-150.
Thoha, M. C. (1994). Teknik Evaluasi Pendidikan. Jakarta: PT. Raja Grafindo Persada.

Umeh, O. J. (2008). The Role of Human Resources Management in Sucsessfull National Development and Government Strategis in Africa and Asia. Public Administration Review, 948-950.

Yukl, G. (2010). Leadership in Organization. (Seventh Ed). New York: Person Education Inc. 